\title{
An Adjunct Treatment Reverses Insulin-dependent (Type 1) Diabetes in a Teenager
}

\author{
Steve Yap*
}

DSY Wellness and Longevity Center, Kuala Lumpur, Malaysia

\begin{abstract}
Globally, more than 30 million people suffer from diabetes mellitus type 1 (T1DM) characterized by pancreas producing little or no insulin hormone to facilitate glucose entering cells for energy production. T1DM patients tend to suffer a higher overall rate of atherosclerosis, cancer, and end-stage renal failure. No drug or surgical therapy seems to halt its annual upward trend amongst children and young adults. Consequently, a significant number of sufferers turn to complementary or alternative therapies for help to arrest this chronic endocrine condition. This paper discusses how a well-designed evidence-based dietary and nutritional therapy with some lifestyle modifications might offer a solution for this highly complex autoimmune disorder. The treatment outcome demonstrated a partial regeneration of pancreatic islet beta cells with substantial improvement for all relevant serum and urine markers tested.
\end{abstract}

Keywords: Type 1 diabetes mellitus, insulin-dependent diabetes, juvenile diabetes, autoimmune disorder, nutritional therapy.

\section{CASE PRESENTATION}

Lee J., a slim 24-year old weighting $56 \mathrm{~kg}$, worked as an assistant chef at a restaurant serving local delicacies for a small town population in Peninsular Malaysia. He was on insulin injection for the past fifteen years after being diagnosed as suffering from juvenile diabetes (diabetes mellitus type I or T1DM) when he was eight years' old. After been advised by his regular physician to reduce intake of refined starch and sugar during his initial years of administering his daily insulin, he felt that he was not gaining any weight like the rest of his school friends. Concerned about being laughed at as a 'weakling', he decided to resume his favourite noodles, buns, bread, biscuits, titbits, and sweet tropical fruits. He received no serious objections from his prescribing physician after raising this dietary issue with him. Worried about him developing early heart disease or hyperuricemia (elevated blood uric acid levels), his parents had discouraged him from consuming eggs, nuts, seeds, and beans. Over the past decade, the patient noticed that the amount of insulin prescribed for daily injection was raised on several occasions after tests confirmed his serum glucose gradual elevation. Being an insulin-dependent diabetic condition, he was instructed not to leave home without his insulin needle for which his parents paid. Having heard about complementary treatment for diabetes from a relative, he called on DSY Wellness Center to seek advice on how he could organise his diets while minimizing the use of insulin which often

*Address correspondence to this author at the DSY Wellness and Longevity Center, Kuala Lumpur, Malaysia; Tel: 60-3-42701266; Fax: 60-3-42701831; E-mail: dsy@dsywellness.com caused him to suffer from problems associated with hypoglycaemia (low blood glucose).

After reviewing his past and present medical records, the patient was advised to gradually make these dietary modifications with the objective of establishing a regular meal pattern with fairly consistent day-to-day caloric and carbohydrate intake:

(1) Reducing substantially the regular intake of refined starches and sugars which require excessive insulin to process. Insulin is secreted primarily in response to blood glucose although dietary fats and protein augment this glucoseinduced secretion [1]. Instead, most daily calories intake would come from complex carbohydrates such as leafy vegetables, yam, bamboo shoots, lentils, beans, seeds, and nuts. Dietary fiber intake tends to be consistently low and well below the recommended 30 gram /day in most diabetic patients [2-4]. Except for those prone to allergies, health concerns over bean/nut consumption may be unfounded since hyperuricemia is more likely to be induced by the widely available sweet tropical fruits high in fructose [5] for which the patient had several servings daily. Furthermore, beans and nuts are rich in magnesium which levels are often low in youngsters with T1DM [6] due to increased urinary excretion of this mineral despite good glycemic control [7].

(2) Keeping fat intake to less than 30 per cent of total calories to avoid gaining further adipose (fat) tissues during therapy period [8]. 
(3) Reducing intake of trans fatty acids since these man-made fats promote insulin disorders and various other metabolic health problems [9].

(4) Including yellow, green or black tea as beverage. Camellia sinensis (tea) beverages may mildly suppress appetite while reducing glucose and triglycerides by more than $20 \%$ [10].

(5) Adding Momordica charantia L. (cucurbitaceae) to daily vegetable juicing or soup. This bittertasting melon could lower fasting glucose and improve glucose tolerance [11] by increasing glucose uptake [12] in the presence of some insulin [13]. Just 2 grams/day of the unripe melon has hypoglycaemic effect $[14,15]$ with higher dosages comparable to some prescription drugs for treating diabetes [16], but with no nephrotoxicity (kidney damage) or hepatotoxicity (liver damage) [17]. Its antidiabetic compounds include charantin, vicine and polypeptide-p [18], which can lower insulin need even on a high fat diet [19]. Improving glycemic control can improve markers of oxidative stress too $[20,21]$.

(6) Juicing organic and freshly-harvested low-frutose local fruits such as Garcinia mangostana (mangosteen), Mangifera indica (mango) and Psidium guajava (guava). Mangosteen juice may be able to lower blood inflammatory marker Creactive protein scores after just two months' therapy [22]. Freshly harvested unripe mango can also lower blood glucose [23]. Non-GMO (genetically modified organism) guava possesses strong free radical scavenging [24] as well as anti-inflammatory and antiglycative properties [25]. Both its hydrophilic and lipophilic antioxidant activities [26] seem to be contributed by its high ascorbic acid (vitamin C) content [27].

(7) Serving generous amount of spices. Trigonella foenum-graecum L. (fenugreek) contains emblica officinalis, which can lower fasting blood sugar and glycated hemoglobin ( $\mathrm{HbA1c}$ ) levels in diabetes. Cinnamomum Zeylanicum (cinnamon) is a commonly used spice [28] which appears to mimic the effect of insulin. Indeed, many of T1DM patients are aware of the positive effect of cinnamon on their blood glucose levels [29]. It has hypoglycemic effects [30] which can significantly lower $\mathrm{HbA} 1 \mathrm{c}$ score, which is a strong measure of diabetic control [31]. Furthermore, compounds such as the micro- mineral chromium and polyphenols found in cinnamon could improve patient's insulin sensitivity [32].

(8) Adding cooked non-GMO Triticum aestivum (wheat) sprout to salad or vegetable dishes. Its polysaccharides may stimulate insulin production by pancreatic beta-cells and pancreatic islets [33].

The patient was also advised to initiate these lifestyle modifications with immediate effect:

(i) Exercising to improve muscle tone and/or help build a higher muscle mass, which could enhance his body's sensitivity to insulin [34]. Pancreas of a physically active or fit individual tends to secrete less insulin after being served carbohydrates than do physically unfit individuals [35].

(ii) Avoiding 'diet' or 'light' cola or soft drinks since these beverages could make greater demand for insulin [36].

Ceasing to cook protein food with sugary items under high temperatures. Formation in this manner of Advanced Glycated End-products (AGEs) in food could further damage his insulin-secreting beta cells. AGEs are accelerated in diabetes or during hyperglycaemic conditions, but their production also occurs in settings characterized by oxidative stress and chronic inflammation [37].

When the patient's first set of blood and urine test results returned, he was advised to continue his insulin injection or any medication unless his regular physician ordered otherwise. As adjunct therapy, the following nutrients were prescribed to be taken after meals with the reasons explained to him:

(1) Gymnema sylvestre extract: $500 \mathrm{mg}$ three times a day (TID). This herb helps stimulate insulin release from beta cells [38] besides increasing efficiency of this hormone [39]. It also may help regenerate these insulin-producing beta cells $[40,41]$, lower HbA1c scores and increase C-peptide levels in T1DM patients [42].

(2) Multivitamins and minerals: once a day. Some $40 \%$ of patients on complementary therapy take a good combination of multivitamins/minerals [28]. Compared to non-diabetics, diabetics tend 
to excrete significantly more minerals including zinc [43] needed for insulin production.

(3) Chromium polynicotinate: $200 \mathrm{mcg}$ TID. This micromineral can help correct negative chromium balance common in youngsters with T1DM [44]. Being an essential nutrient involved in the metabolism of glucose and insulin, it can reverse glucose intolerance and neuropathy in T1DM [45] although dosages lower than $200 \mathrm{mcg} /$ day are unlikely to be effective [46].

(4) Alpha lipoic acid (ALA): 200mg TID. Being an essential cofactor for mitochondrial bioenergetic enzymes, this nutrient improves glycemic control, prevents diabetic neuropathy [47, 48], treats different forms of autonomic diabetic neuropathy [49], improves microcirculation [50], and ameliorates pathophysiologies of many chronic diseases [51]. Elevated $\mathrm{HbA} 1 \mathrm{c}$ raises risk of diabetic retinopathy, which is found in up to $60 \%$ of TIDM patients aged 20 and above [52]. Diabetes is associated with elevated oxidative stress including DNA-damaging hydroxyl radical formation [53].

Vitamin A: 10,000 IU twice a day (BID). This fatsoluble vitamin has immuno-modulatory effects, which are relatively deficient in subjects with established T1DM [54]. Consequently, diets rich in polyphenols and/or vitamin A have protective effects against autoimmune inflammatory attack of the islet beta cells and they have the potential to reduce the pathogenesis of autoimmune diabetes $[55,56]$.

(6) Mixed tocopherols: 400 IU BID. Vitamin E ameliorates oxidative stress in T1DM and improves antioxidant defence system [57]. Even a modest supplementation can lower $\mathrm{HbA} 1 \mathrm{c}$ and triglyceride levels in T1DM patients [58]. Free radical mediated oxidative stress can play a major role in the pathogenesis of diabetes. The glycation of proteins and elevated serum triglyceride levels are two of the major risk factors in the development of complications of diabetes. Vitamin $\mathrm{E}$ helps protect residual beta cell function of the pancreas [59].

(7) Ascorbic acid: 1g TID. Chronic hyperglycemia in T1DM patients induces permanent alterations of their endothelial function by increased oxidative stress, even after glycemia is normalized. As a strong antioxidant, vitamin C can normalize endothelial function in these patients [60] and slow progression in hypertension and/or heart disease. It reduces sorbitol accumulation in erythrocytes promoted by hyperglycemia [61] by inhibiting the enzyme erythrocyte aldose reductase [62].

(8) Folate: $800 \mathrm{mcg}$ BID. Endothelial dysfunction, a precursor of vascular disease, begins early in T1DM and is associated with low folate status with high-dose folate normalizing endothelial dysfunction $[63,64]$, although it does not seem to do so in non-diabetics even if obese [65].

(9) Nicotinamide: $500 \mathrm{mg}$ TID. This non-flushing vitamin B3 inhibits poly (ADP-ribose) polymerase, reduces nitric oxide accumulation in pancreas, and can protect beta cells against radical-induced necrosis [66]. It can preserve baseline C-peptide secretion [67], which augments blood flow in skeletal muscle and skin, diminishes glomerular hyperfiltration, reduces urinary albumin excretion, and improves nerve function in patients with T1DM [68]. Just $25 \mathrm{mg} /$ $\mathrm{kg}$ of body weight seems effective in reducing insulin-producing beta-cell dysfunction [69].

(10) Vitamin D3: 4000 IU TID. Of the various environmental causes, this anti-autoimmune vitamin is rather well-studied in relation to T1DM [70-74]. Patients may achieve lower HbA1c levels if they have higher serum 25hydroxyvitamin D levels [75], although some studies showed only a small positive effect on fasting glucose [76].

(11) Magnesium citrate (elemental value 16\%): $1 \mathrm{~g}$ TID. One in four diabetic patients [77] may suffer from hypomagnesemia, which can lead to poor diabetic control with higher HbA1c scores [78], early atherosclerosis [79] and microalbuminuria [80]. Its deficiency can cause retinopathy and hypertension [81], metabolic syndrome [82], and chronic diabetic complications [83] since it is a co-factor in more than 300 different enzyme systems in the body [84]. Insulin injection can enhance renal magnesium excretion [85]. Supplementation can improve insulin sensitivity and may stimulate insulin secretion [86].

\section{DISCUSSION}

T1DM is characterized by the infiltration of activated T-lymphocytes and monocytes into the islets of 
Langerhans of the pancreas, resulting in chronic inflammation and progressive destruction of the insulinproducing beta cells [87, 88]. Activated T-cells and cytokines secreted from immunocytes act synergistically to destroy these beta cells resulting in the development of this autoimmune disease [89]. Once islet auto-antibodies have developed, the progression to diabetes in antibody-positive individuals is determined by the age of antibody appearance and by the magnitude of the autoimmunity [90]. Globally, some 33 million people suffer from T1DM and its incidence increases by about $3 \%$ annually among children [91]. T1DM patients appear to face a higher overall incidence of cancer [92] and end-stage renal failure [93].

Vitamin D receptor (VDR) gene polymorphisms may determine risk of developing T1DM with the environment influencing the association between VDR genotype and T1DM risks [72]. The disorder commonly begins during childhood but may appear later in adulthood in a proportion of 30 to $40 \%$ of affected individuals [94].

Parent's eating habits and the home food environment such as its accessibility and availability are important determinant of their children's dietary intake $[95,96]$. The likelihood of children making positive changes to their diets will be increased if their parents are involved and supportive. Vegetables and low-fructose citric fruits consumption should be raised [97], while long-chain saturated fats intake should be lowered [98, 99] since atherosclerosis may be wellestablished when T1DM children reach adolescence $[100,101]$.

Increased intake of omega-3 fatty acids and fish oil is linked to reduced T1DM-associated autoantibody conversion [102]. Use of cod liver oil rich in vitamins A and $D$ in the first year of life is associated with a significantly lower risk of T1DM [103]. Vitamin D3 supplementation in early childhood can offer protection against the development of T1DM [73, 104] as well as helping to reverse its increasing incidence [105].

A long list of environmental factors influences the risks for or progression to T1DM [87], which condition is on the rise globally [106] and especially in children [107]. The presence of multiple autoantibodies seems to have the highest positive predictive value for development of T1DM [108, 109]. Insulin autoantibodies, in contrast to the other autoimmune markers, are the only beta-cell specific antibodies [110].
There may be a link between viral infections and the first appearance or increase in islet antibodies [111113] although the evidence is weak $[114,115]$. However, viral infection of antigen presenting cells can locally raise inflammation and auto-reactive lymphocytes [116].

An early onset of T1DM can raise the child's risk of learning disability [117]. Difficulties in diagnosing T1DM are a significant cause of diabetic ketoacidosis development in children with new-onset disease [118].

A cure for T1DM may require the provision or elicitation of new pancreatic islet beta cells as well as the reestablishment of immunological tolerance [119]. The limited regenerative ability of the endocrine pancreas may be linked to the defined number of pancreatic progenitors, which is generally incapable of compensatory growth in response to cell loss [120]. The inability to cure this chronic disorder is largely because of its highly complex pathophysiology [121].

Some $28 \%$ of the population in developed nations depends on complementary and alternatives modalities to treat their T1DM [28] although there seems to be insufficient research evidence to support differing nutritional needs for those with T1DM compared to type 2 diabetes [122].

\section{The Diagnosis}

The patient suffered from most of the major symptoms of juvenile diabetes such as polyuria (frequent urination), polydipsia (increased thirst), polyphagia (increased hunger), and weight loss [123]. His dramatically reduced $\mathrm{HbA} 1 \mathrm{c}$ score after three months' therapy suggested a much lower level of glycated hemoglobin and a stronger diabetic control. Such a score could also be linked to his lower triglyceride levels [99]. The fasting insulin and glucose levels in November 2013 would suggest his pancreatic islet beta cells were releasing adequate insulin to meet his needs after some dietary modifications. This supports long-held belief that there would still be some functional beta cells in people with longstanding T1DM [124]. His chronic inflammatory conditions improved five-fold accompanied by much lower level urine microalbumin. The patient was delighted with the disappearance of any glucose from his urine sample taken at the end of the third month of therapy. This positive outcome was confirmed by the patient's regular physician, who then advised a temporary halt to the administration of insulin pending further monitoring. 
Extracts from the patient's three months' test results for 2013 were as follow:

\begin{tabular}{|c|c|c|c|c|}
\hline & Aug & Sept & Oct & Nov \\
\hline \multicolumn{5}{|l|}{ Serum } \\
\hline Fasting insulin $(2-25 \mathrm{ulU} / \mathrm{ml}) \#$ & $<2$ & $<2$ & 5 & 16 \\
\hline Fasting glucose $(<115 \mathrm{mg} / \mathrm{dl})$ & 253 & 218 & 167 & 104 \\
\hline $\mathrm{HbA} 1 \mathrm{c}(<5 \%)$ & 8.3 & 7.2 & 6.4 & 5.9 \\
\hline hs-CRP (<1.0mg/L) & 15.9 & 11.7 & 7.3 & 2.8 \\
\hline Fibrinogen $(2-4 \mathrm{~g} / \mathrm{dl})$ & 5.3 & 4.5 & 3.9 & 3.1 \\
\hline Triglycerides (<150mg/dL) & 312 & 287 & 242 & 159 \\
\hline \multicolumn{5}{|c|}{ \# Morning scores without insulin injection for 12 hours } \\
\hline \multicolumn{5}{|l|}{$\underline{\text { Urine }}$} \\
\hline Glucose (nil) & **** & ** & * & nil \\
\hline Microalbumin $(<3.4 \mathrm{mg} / \mathrm{mmol})$ & 23.2 & 16.7 & 9.5 & 4.2 \\
\hline
\end{tabular}

Although cytokines such as IL-1alpha, IL-1beta and IFN-gamma are widely implicated in the pathogenesis of autoimmune diabetes [125], local laboratories were unable to test these markers.

The patient was using the insulin pump and with flexible injection regimens designed for him to lead a normal lifestyle [126]. However, initial test results suggested his inability to benefit fully from these modern conventional therapies.

\section{CONCLUSION}

The health outcome achieved by the patient suggested some form of pancreatic cell mass regeneration consequent upon undertaking this nutritional therapy which involved some lifestyle modifications. Further study involving a higher number of patients with similar conditions is warranted to elucidate its wider therapeutic benefits in the treatment of T1DM.

\section{REFERENCES}

[1] Fu Z, Gilbert ER, Liu D. Regulation of insulin synthesis and secretion and pancreatic Beta-cell dysfunction in diabetes. Curr Diabetes Rev 2013; 9(1): 25-53. http://dx.doi.org/10.2174/1573399811309010025

[2] Helgeson VS, Viccaro L, Becker D, Escobar O, Siminerio L. Diet of adolescents with and without diabetes: Trading candy for potato chips? Diabetes Care 2006; 29(5): 982-7. http://dx.doi.org/10.2337/dc05-219

[3] Lodefalk $M$ and Aman J. Food habits, energy and nutrient intake in adolescents with Type 1 diabetes mellitus. Diabet Med 2006; 23: 1225-32. http://dx.doi.org/10.1111/j.1464-5491.2006.01971.x

[4] Randecker GA, Smiciklas-Wright H, McKenzie JM, Shannon $\mathrm{BM}$, Mitchell DC, et al. The dietary intake of children with IDDM. Diabetes Care.1996; 19: 1370-4.
[5] Johnson RJ, Segal MS, Sautin Y, Nakagawa T, Feig DI et al. Potential role of sugar (fructose) in the epidemic of hypertension, obesity and the metabolic syndrome, diabetes, kidney disease, and cardiovascular disease. Am J Clin Nutr 2007; 86(4): 899-906.

[6] Fort P, Lifshitz F. Magnesium status in children with insulindependent diabetes mellitus. J Am Coll Nutr 1986; 5(1): 6978.

[7] Ponder SW, Brouhard BH, Travis LB. Hyperphosphaturia and hypermagnesuria in children with IDDM. Diabetes Care 1990; 13(4) : 437-41.

[8] Bantle J. The dietary treatment of diabetes mellitus. Med Clin North Am 1988; 72(6): 1285-99.

[9] Ascherio A and Willett W. Health effects of trans fatty acids. Am J Clin Nutr, 1997; 66: 1006-10.

[10] Zeyuan D, Bingying T, Xiaolin L, Jinming H, Yifeng C. Effect of green tea and black tea on the metabolisms of mineral elements in old rats. Biol Trace Elem Res 1998; 65(1): 75-86.

[11] Raman A, Lau C. Anti-diabetic properties and phytochemistry of Momordica charantia L. (Cucurbitaceae). Phytomedicine 1996; 2(4): 349-62. http://dx.doi.org/10.1016/S0944-7113(96)80080-8

[12] Yibchok-anun S, Adisakwattana S, Yao CY, Sangvanich P, Roengsumran $\mathrm{S}$, et al. Slow acting protein extract from fruit pulp of Momordica charantia with insulin secretagogue and insulinomimetic activities. Biol Pharm Bull 2006; 29(6): 112631 http://dx.doi.org/10.1248/bpb.29.1126

[13] Roffey BW, Atwal AS, Johns T, Kubow S. Water extracts from Momordica charantia increase glucose uptake and adiponectin secretion in 3T3-L1 adipose cells. J Ethnopharmacol 2007; 112(1): 77-84. http://dx.doi.org/10.1016/j.jep.2007.02.003

[14] Fuangchan A, Sonthisombat $P$, Seubnukarn T, Chanouan R, Chotchaisuwat $\mathrm{P}$, et al. Hypoglycemic effect of bitter melon compared with metformin in newly diagnosed type 2 diabetes patients. J Ethnopharmacol 2011; 134(2): 422-8. http://dx.doi.org/10.1016/i.jep.2010.12.045

[15] Khanna P, Jain SC, Panagariya A, Dixit VP. Hypoglycemic activity of polypeptide-p from a plant source. J Nat Prod 1981; 44: 648-55.

[16] Sarkar S, Pranava M, Marita R. Demonstration of the hypoglycemic action of Momordica charantia in a validated animal model of diabetes. Pharmacol Res 1996; 33(1): 1-4.

[17] Virdi J, Sivakami S, Shahani S, Suthar AC, Banavalikar MM, et al. Antihyperglycemic effects of three extracts from 
Momordica charantia. J Ethnopharmacol 2003; 88(1): 107-11.

http://dx.doi.org/10.1016/S0378-8741(03)00184-3

[18] Krawinkel MB, Keding GB. Bitter gourd (Momordica Charantia): A dietary approach to hyperglycemia. Nutr Rev 2006; 64(7 Pt 1): 331-7.

http://dx.doi.org/10.1111/j.1753-4887.2006.tb00217.x

[19] Chen Q, Chan LL, Li ET. Bitter melon (Momordica charantia) reduces adiposity, lowers serum insulin and normalizes glucose tolerance in rats fed a high fat diet. J Nutr 2003; 133(4): 1088-93

[20] Sharma A, Kharb S, Chugh SN, Kakkar R, Singh GP. Evaluation of oxidative stress before and after control of glycemia and after vitamin E supplementation in diabetic patients. Metabolism 2000; 49: 160-2.

[21] Santini SA, Marra G, Giardina B, Cottroneo P, Mordente A, Martorana GE, et al. Defective plasma antioxidant defenses and enhanced susceptibility to lipid peroxidation in uncomplicated IDDM. Diabetes 1997; 46: 1853-8.

[22] Udani JK, Singh BB, Barrett ML, Singh VJ. Evaluation of mangosteen juice blend on biomarkers of inflammation in obese subjects: a pilot, dose finding study. Nutr J 2009; 8: 48.

http://dx.doi.org/10.1186/1475-2891-8-48

[23] Lucas EA, Li W, Peterson SK, Brown A, Kuvibidila S, et al. Mango modulates body fat and plasma glucose and lipids in mice fed a high-fat diet. Br J Nutr 2011; 106(10): 1495-505. http://dx.doi.org/10.1017/S0007114511002066

[24] Adesida A, Farombi EO. Free radical scavenging activities of guava extract in vitro. Afr J Med Med Sci 2012; 41(S): 81-90.

[25] Lin CY, Yin MC. Renal protective effects of extracts from guava fruit (Psidium guajava L.) in diabetic mice. Plant Foods Hum Nutr 2012; 67(3): 303-8. http://dx.doi.org/10.1007/s11130-012-0294-0

[26] Thaipong K, Boonprakob U, Cisneros-Zevallos L, Byrne DH. Hydrophilic and lipophilic antioxidant activities of guava fruits. Southeast Asian J Trop Med Public Health 2005; 36(S4): 254-7.

[27] Thuaytong W, Anprung P. Bioactive compounds and prebiotic activity in Thailand-grown red and white guava fruit (Psidium guajava L.). Food Sci Technol Int 2011; 17(3): 20512. http://dx.doi.org/10.1177/1082013210382066

[28] Manya K, Champion B, Dunning T. The use of complementary and alternative medicine among people living with diabetes in Sydney. BMC Complement Altern Med 2012; 12: 2. http://dx.doi.org/10.1186/1472-6882-12-2

[29] Fabian E, Toscher S, Elmadfa I, Pieber TR.Use of complementary and alternative medicine supplements in patients with diabetes mellitus. Ann Nutr Metab 2011; 58(2): 101-8. http://dx.doi.org/10.1159/000326765

[30] Deng RT. A review of the hypoglycemic effects of five commonly used herbal food supplements. Recent Pat Food Nutr Agric 2012; 4(1): 50-60. http://dx.doi.org/10.2174/2212798411204010050

[31] Akilen R, Tsiami A, Devendra D, Robinson N. Cinnamon in glycaemic control: Systematic review and meta-analysis. Clin Nutr 2012; 31(5): 609-15. http://dx.doi.org/10.1016/j.clnu.2012.04.003

[32] Anderson RA. Chromium and polyphenols from cinnamon improve insulin sensitivity. Proc Nutr Soc 2008; 67(1): 48-53. http://dx.doi.org/10.1017/S0029665108006010

[33] Lee SH, Lim SW, Lee YM, Lee HS, Kim DK. Polysaccharide isolated from Triticum aestivum stimulates insulin release from pancreatic cells via the ATP-sensitive $\mathrm{K}+$ channel. Int $\mathrm{J}$ Mol Med 2012; 29(5): 913-9.

http://dx.doi.org/10.3892/ijmm.2012.905
[34] Mayer-Davis EJ, D'Agostino R Jr, Karter AJ, Haffner SM, Rewers MJ, et al. Intensity and amount of physical activity in relation to insulin sensitivity: The Insulin Resistance Atherosclerosis Study. JAMA 1998; 279: 669-74.

http://dx.doi.org/10.1001/jama.279.9.669

[35] Helmrich SP, Ragland DR, Leung RW, Paffenbarger RS Jr. Physical activity and reduced occurance of non-insulin dependent diabetes mellitus. N Eng J Med.1991; 325: 14752.

\section{http://dx.doi.org/10.1056/NEJM199107183250302}

[36] Fowler SP, Williams K, Resendez RG, Hunt KJ, Hazuda HP et al. Fuelling the obesity epidemic? Artificially sweetened beverage use and long-term weight gain. Obesity (Silver Spring) 2008; 16(8): 1894-900.

http://dx.doi.org/10.1038/oby.2008.284

[37] Del Turco $S$ and Basta G. An update on advanced glycation endproducts and atherosclerosis. Biofactors 2012; 10: 100218.

http://dx.doi.org/10.1002/biof.1018

[38] Persaud SJ, Al-Majed H, Raman A, Jones PM. Gymnema sylvestre stimulates insulin release in vitro by increased membrane permeability. J Endocrinol 1999; 163(2): 207-12. http://dx.doi.org/10.1677/joe.0.1630207

[39] Baskaran K, Kizar Ahamath B, Radha Shanmugasundaram $\mathrm{K}$, Shanmugasundaram ER. Antidiabetic effect of a leaf extract from Gymnema sylvestre in non-insulin-dependent diabetes mellitus patients. J Ethnopharmacol 1990; 30(3): 295-300.

[40] Liu B, Asare-Anane H, Al-Romaiyan A, Huang G, Amiel SA et al. Characterisation of the insulinotropic activity of an aqueous extract of Gymnema sylvestre in mouse beta-cells and human islets of Langerhans. Cell Physiol Biochem 2009; 23(1-3): 125-32. http://dx.doi.org/10.1159/000204101

[41] Shanmugasundaram ER, Gopinath KL, Radha Shanmugasundaram K, Rajendran VM. Possible regeneration of the islets of Langerhans in streptozotocindiabetic rats given Gymnema sylvestre leaf extracts. J Ethnopharmacol 1990; 30(3): 265-79.

[42] Shanmugasundaram ER, Rajeswari G, Baskaran K, Rajesh Kumar BR, Radha Shanmugasundaram K, et al. Use of Gymnema sylvestre leaf extract in the control of blood glucose in insulin-dependent diabetes mellitus. J Ethnopharmacol 1990; 30(3): 281-94.

[43] el-Yazigi A, Hannan N, Raines DA. Effect of diabetic state and related disorders on the urinary excretion of magnesium and zinc in patients. Diabetes Res 1993; 22(2): 67-75.

[44] Karagun BS, Temiz F, Ozer G, Yuksel B, Topaloglu AK, et al Chromium levels in healthy and newly diagnosed type 1 diabetic children. Pediatr Int 2012; 54(6): 780-5. http://dx.doi.org/10.1111/j.1442-200X.2012.03696.x

[45] Anderson RA. Chromium in the prevention and control of diabetes. Diabetes Metab 2000; 26(1): 22-7. http://dx.doi.org/DM-03-2000-26-1-1262-3636-101019ART67

[46] Guimaraes MM, Martins Silva Carvalho AC, Silva MS Chromium nicotinate has no effect on insulin sensitivity, glycemic control, and lipid profile in subjects with type 2 diabetes. J Am Coll Nutr 2013; 32(4): 243-50. http://dx.doi.org/10.1080/07315724.2013.816598

[47] Golbidi S, Badran M, Laher I. Diabetes and alpha lipoic Acid. Front Pharmacol 2011; 2: 69. http://dx.doi.org/10.3389/fphar.2011.00069

[48] Singh $U$ and Jialal I. Alpha-lipoic acid supplementation and diabetes. Nutr Rev 2008; 66(11): 646-57. http://dx.doi.org/10.1111/j.1753-4887.2008.00118.x

[49] Tankova T, Koev D, Dakovska L. Alpha-lipoic acid in the treatment of autonomic diabetic neuropathy (controlled, 
randomized, open-label study). Rom J Intern Med 2004; 42(2): 457-64.

[50] Ziegler D. Thioctic acid for patients with symptomatic diabetic polyneuropathy: a critical review. Treat Endocrinol 2004; 3(3): 173-89.

[51] Smith AR, Shenvi SV, Widlansky M, Suh JH, Hagen TM. Lipoic acid as a potential therapy for chronic diseases associated with oxidative stress. Curr Med Chem 2004; 11(9): 1135-46.

http://dx.doi.org/10.2174/0929867043365387

[52] Olsen BS, Sjølie AK, Hougaard P, Johannesen J, Marinelli K, et al. The significance of the prepubertal diabetes duration for the development of retinopathy and nephropathy in patients with type 1 diabetes. J Diabetes Complications 2004; 18(3): 160-4.

http://dx.doi.org/10.1016/S1056-8727(03)00073-4

[53] Suzen S, Buyukbingol E. Recent studies of aldose reductase enzyme inhibition for diabetic complications. Curr Med Chem 2003; 10(15): 1329-52.

http://dx.doi.org/10.2174/0929867033457377

[54] Baena RM, Campoy C, Bayés R, Blanca E, Fernández JM. Vitamin $\mathrm{A}$, retinol binding protein and lipids in type 1 diabetes mellitus. Eur J Clin Nutr 2002; 56: 44-50. http://dx.doi.org/10.1038/sj/ejcn/1601279

[55] Wasserfall $C$ and Atkinson M. Taking a Daily Vitamin to Prevent Type 1 Diabetes? Diabetes 2009; 58(1): 24-5. http://dx.doi.org/10.2337/db08-1479

[56] Zunino SJ, Storms DH, Stephensen CB. Diets rich in polyphenols and vitamin A inhibit the development of type I autoimmune diabetes in nonobese diabetic mice. J Nutr 2007; 137(5): 1216-21.

[57] Gupta S, Sharma TK, Kaushik GG, Shekhawat VP. Vitamin E supplementation may ameliorate oxidative stress in type 1 diabetes mellitus patients. Clin Lab 2011; 57(5-6): 379-86.

[58] Jain SK, McVie R, Jaramillo JJ, Palmer M, Smith T. Effect of modest vitamin $\mathrm{E}$ supplementation on blood glycated hemoglobin and triglyceride levels and red cell indices in type I diabetic patients. J Am Coll Nutr 1996; 15(5): 458-61.

[59] Pozzilli P, Visalli N, Cavallo MG, Signore A, Baroni MG et al. Vitamin $E$ and nicotinamide have similar effects in maintaining residual beta cell function in recent onset insulindependent diabetes (the IMDIAB IV study). Eur J Endocrinol 1997; 137(3): 234-9. http://dx.doi.org/10.1530/eje.0.1370234

[60] Ceriello A, Piconi L, Esposito K, Giugliano D. Telmisartan shows an equivalent effect of vitamin $\mathrm{C}$ in further improving endothelial dysfunction after glycemia normalization in type 1 diabetes. Diabetes Care 2007; 30(7): 1694-8. http://dx.doi.org/10.2337/dc07-0318

[61] Cunningham JJ, Mearkle PL, Brown RG. Vitamin C: an aldose reductase inhibitor that normalizes erythrocyte sorbitol in insulin-dependent diabetes mellitus. J Am Coll Nutr 1994; 13(4): 344-50.

[62] Vincent TE, Mendiratta S, May JM. Inhibition of aldose reductase in human erythrocytes by vitamin $\mathrm{C}$. Diabetes Res Clin Pract 1999; 43(1): 1-8.

[63] MacKenzie KE, Wiltshire EJ, Gent R, Hirte C, Piotto L, et al. Folate and vitamin B6 rapidly normalize endothelial dysfunction in children with type 1 diabetes mellitus. Pediatrics 2006; 118(1): 242-53. http://dx.doi.org/10.1542/peds.2005-2143

[64] Pena AS, Wiltshire E, Gent R, Hirte C, Couper J. Folic acid improves endothelial function in children and adolescents with type 1 diabetes. J Pediatr 2004; 144(4): 500-4. http://dx.doi.org/10.1016/j.jpeds.2003.12.049

[65] Pena AS, Wiltshire E, Gent R, Piotto L, Hirte C, Couper J. Folic acid does not improve endothelial function in obese children and adolescents. Diabetes Care 2007; 30(8): 21227. http://dx.doi.org/10.2337/dc06-2505
[66] Kawasaki E, Abiru N, Eguchi K. Prevention of type 1 diabetes: from the view point of beta cell damage. Diabetes Res Clin Pract 2004; 66(S1): S27-32. http://dx.doi.org/10.1016/i.diabres.2003.09.015

[67] Crino A, Schiaffini R, Manfrini S, Mesturino C, Visalli N, et al. $A$ randomized trial of nicotinamide and vitamin $E$ in children with recent onset type 1 diabetes (IMDIAB IX). Eur J Endocrinol 2004; 150(5): 719-24. http://dx.doi.org/10.1530/eje.0.1500719

[68] Wahren J , Ekberg K , Johansson J , Henriksson $M$, Pramanik $A$, et al. Role of C-peptide in human physiology. Am J Physiol Endocrinol Metab 2000; 278(5): E759-68.

[69] Visalli N, Cavallo MG, Signore A, Baroni MG, Buzzetti R, et al. A multi-centre randomized trial of two different doses of nicotinamide in patients with recent-onset type 1 diabetes (the IMDIAB VI). Diabetes Metab Res Rev 1999; 15(3): 1815. http://dx.doi.org/10.1002/(SICI)15207560(199905/06)15:3<181::AID-DMRR31>3.0.CO;2-H

[70] Bener A, Alsaied A, Al-Ali M, Al-Kubaisi A, Basha B, et al. High prevalence of vitamin $D$ deficiency in type 1 diabetes mellitus and healthy children. Acta Diabetol 2009; 46(3): 1839.

\section{http://dx.doi.org/10.1007/s00592-008-0071-6}

[71] Vojtkova J, Ciljakova M, Vojarova L, Janíkova K, Michnova Z, et al. Hypovitaminosis $\mathrm{D}$ in children with type 1 diabetes mellitus and its influence on biochemical and densitometric parameters. Acta Medica (Hradec Kralove) 2012; 55(1): 1822.

[72] Ponsonby AL, Pezic A, Ellis J, Morley R, Cameron F, et al. Variation in associations between allelic variants of the vitamin $D$ receptor gene and onset of type 1 diabetes mellitus by ambient winter ultraviolet radiation levels: a metaregression analysis. Am J Epidemiol 2008; 168: 358-65. http://dx.doi.org/10.1093/aje/kwn142

[73] Zipitis CS and Akobeng AK. Vitamin D supplementation in early childhood and risk of type 1 diabetes: a systematic review and meta-analysis. Arch Dis Child 2008; 93(6): 512-7. http://dx.doi.org/10.1136/adc.2007.128579

[74] Ramos-Lopez E, Brück P, Jansen T, Herwig J, Badenhoop K. CYP2R1 (vitamin D 25-hydroxylase) gene is associated with susceptibility to type 1 diabetes and vitamin $D$ levels in Germans. Diabete Metab Res Rev 2007; 23: 631-6. http://dx.doi.org/10.1002/dmrr.719

[75] Aljabri KS, Bokhari SA, Khan MJ. Glycemic changes after vitamin $\mathrm{D}$ supplementation in patients with type 1 diabetes mellitus and vitamin D deficiency. Ann Saudi Med 2010; 30(6): 454-8.

http://dx.doi.org/10.4103/0256-4947.72265

[76] George PS, Pearson ER, Witham MD. Effect of vitamin D supplementation on glycaemic control and insulin resistance: a systematic review and meta-analysis. Diabet Med 2012; 29(8): e142-50.

http://dx.doi.org/10.1111/j.1464-5491.2012.03672.x

[77] Mather HM, Nisbet JA, Burton GH, Poston GJ, Bland JM, et al. Hypomagnesemia in diabetes. Clin Chim Acta 1979; 95 235-42.

[78] Vanroelen WF, Van Gaal LF, Van Rooy PE, De Leeuw IH. Serum and erythrocyte magnesium levels in type I and type II diabetics. Acta Diabetol Lat 1985; 22(3): 185-90.

[79] Atabek ME, Kurtoglu S, Pirgon O, Baykara M. Serum magnesium concentrations in type 1 diabetic patients: relation to early atherosclerosis. Diabetes Res Clin Pract 2006; 72(1): 42-7. http://dx.doi.org/10.1016/j. diabres.2005.09.002

[80] Xu B, Sun J, Deng X, Huang X, Sun W, et al. Low serum magnesium level is associated with microalbuminuria in Chinese diabetic patients. Int J Endocrinol 2013; 2013: 580685 .

http://dx.doi.org/10.1155/2013/580685 
[81] Sharma A, Dabla S, Agrawal RP, Barjatya H, Kochar DK, et al. Serum magnesium: an early predictor of course and complications of diabetes mellitus. J Indian Med Assoc 2007; 105(1): 16, 18, 20.

[82] He K, Liu K, Daviglus ML, Morris SJ, Loria CM, et al. Magnesium intake and incidence of metabolic syndrome among young adults. Circulation 2006; 113(13): 1675-82 http://dx.doi.org/10.1161/CIRCULATIONAHA.105.588327

[83] Elamin A, Tuvemo T. Magnesium and insulin-dependent diabetes mellitus. Diabetes Res Clin Pract 1990; 10(3): 2039.

[84] Wester PO. Magnesium. Am J Clin Nutr 1987; 45(5 Suppl): 1305-12.

[85] Djurhuus MS, Sktt $P$, Hother-Nielsen O, Klitgaard $N A H$, Beck-Nielsen $\mathrm{H}$. Insulin increases renal magnesium excretion. Diabet Med 1995; 12: 664-9.

[86] de Valk HW. Magnesium in diabetes mellitus. Neth $\mathrm{J}$ Med 1999; 54(4): 139-46.

[87] Atkinson $M$ and Eisenbarth G. Type 1 diabetes: new perspectives on disease pathogenesis and treatment. The Lancet 2001; 358: 221-9.

http://dx.doi.org/10.1016/S0140-6736(01)05415-0

[88] Shapiro AM, Lakey JR, Ryan EA, Korbutt GS, Toth E, et al. Islet transplantation in seven patients with type 1 diabetes mellitus using a glucocorticoid-free immunosuppressive regimen. N Engl J Med 2000; 343(4): 230-8. http://dx.doi.org/10.1056/NEJM200007273430401

[89] Yoon JW and Jun HS. Cellular and molecular pathogenic mechanisms of insulin-dependent diabetes mellitus. Ann N Y Acad Sci 2001; 928: 200-11. http://dx.doi.org/10.1111/j.1749-6632.2001.tb05650.x

[90] Achenbach P, Bonifacio E, Koczwara K, Ziegler AG. Natural history of type 1 diabetes. Diabetes 2005; 54(S2): S25-31. http://dx.doi.org/10.2337/diabetes.54.suppl_2.S25

[91] Gordon-Dseagu V, Shelton N, Mindell J. Epidemiological evidence of a relationship between type-1 diabetes mellitus and cancer: a review of the existing literature. Int $\mathrm{J}$ Cancer 2013; 132(3): 501-8.

http://dx.doi.org/10.1002/ijc.27703

[92] Zendehdel K, Nyrén O, Ostenson CG, Adami HO, Ekbom A, et al. Cancer incidence in patients with type 1 diabetes mellitus: a population-based cohort study in Sweden. J Natl Cancer Inst 2003; 95(23): 1797-800.

http://dx.doi.org/10.1093/jnci/djg105

[93] Krolewski AS, Bonventre JV. High risk of ESRD in type 1 diabetes: call for action: introduction. Semin Nephrol 2012; 32(5): 405-6.

http://dx.doi.org/10.1016/j.semnephrol.2012.07.001

[94] Fandrich F, Ungefroren H. Customized cell-based treatment options to combat autoimmunity and restore beta-cell function in type 1 diabetes mellitus: current protocols and future perspectives. Adv Exp Med Biol 2010; 654: 641-65. http://dx.doi.org/10.1007/978-90-481-3271-3 28

[95] Arcan C, Neumark-Sztainer D, Hannan P, van den Berg P, Story $\mathrm{M}$, et al. Parental eating behaviours, home food environment and adolescent intakes of fruits, vegetables and dairy foods: longitudinal findings from Project EAT. Public Health Nutr 2008; 10: 1257-65. http://dx.doi.org/10.1017/S1368980007687151

[96] Cullen KW, Baranowski T, Owens E, Marsh T, Rittenberry L, de Moor C. Availability, accessibility, and preferences for fruit, $100 \%$ fruit juice and vegetables influence children's dietary behavior. Health Edu \& Behavior 2003; 30(5): 615-26. http://dx.doi.org/10.1177/1090198103257254

[97] Mayer-Davis EJ, Nichols M, Liese AD, Bell RA, Dabelea DM, et al. Dietary intake among youth with diabetes: the SEARCH for Diabetes in Youth Study. J Am Diet Assoc 2006; 106(5): 689-97.

http://dx.doi.org/10.1016/.jada.2006.02.002
[98] Overby NC, Flaaten V, Veierød MB, Bergstad I, Margeirsdottir HD, et al. Children and adolescents with type 1 diabetes eat a more atherosclerosis-prone diet than healthy control subjects. Diabetologia 2007; 50: 307-16.

http://dx.doi.org/10.1007/s00125-006-0540-9

[99] Faulkner MS, Chao WH, Kamath SK, Quinn L, Fritschi C, et al. Homocysteine, Diet, and Lipid Profiles in Type 1 and Type 2 Diabetic Nondiabetic Adolescents. J Cardiovasc Nurs 2006; 21: 47-55.

[100] Jarvisalo MJ, Putto-Laurila A, Jartti L, Lehtimaki T, Solakivi T, Carotid artery intima-media thickness in children with type 1 diabetes. Diabetes 2002; 51: 493-8. http://dx.doi.org/10.2337/diabetes.51.2.493

[101] Berenson GS, Srinivasan SR, Bao WH, Newman WP, Tracy $\mathrm{RE}$, et al. Association between multiple cardiovascular risk factors and atherosclerosis in children and young adults. $\mathrm{N}$ Engl J Med 1998; 338: 1650-6. http://dx.doi.org/10.1056/NEJM199806043382302

[102] Norris JM, Yin X, Lamb MM, Barriga K, Seifert J, et al. Omega-3 polyunsaturated fatty acid intake and islet autoimmunity in children at increased risk for type 1 diabetes. JAMA 2007; 298(12): 1420-8. http://dx.doi.org/10.1001/jama.298.12.1420

[103] Stene LC, Joner G; Norwegian Childhood Diabetes Study Group. Use of cod liver oil during the first year of life is associated with lower risk of childhood-onset type 1 diabetes: a large, population-based, case-control study. Am J Clin Nutr 2003; 78(6): 1128-34.

[104] Lamberg-Allardt C. Vitamin D in children and adolescents. Scand J Clin Lab Invest Suppl 2012; 243: 124-8. http://dx.doi.org/10.3109/00365513.2012.682885

[105] Hypponen E, Laara E, Reunanen A, Jarvelin MR, Virtanen SM. Intake of vitamin $D$ and risk of type 1 diabetes: a birthcohort study. The Lancet 2001; 358(9292): 1500-3. http://dx.doi.org/10.1016/S0140-6736(01)06580-1

[106] Dahlquist G. Can we slow the rising incidence of childhoodonset autoimmune diabetes? The overload hypothesis. Diabetologia 2006; 49: 20-4.

[107] Gale EA. The rise of childhood type 1 diabetes in the 20th century. Diabetes 2002; 51: 3353-61. http://dx.doi.org/10.2337/diabetes.51.12.3353

[108] Pihoker C, Gilliam LK, Hampe CS, Lernmark A Autoantibodies in diabetes. Diabetes 2005; 54(S2): S52-61. http://dx.doi.org/10.2337/diabetes.54.suppl_2.S52

[109] Bach JF. Insulin-dependent diabetes mellitus as an autoimmune disease. Endocr Rev 1994; 15(4): 516-42. http://dx.doi.org/10.1210/edrv-15-4-516

[110] Franke B, Galloway TS, Wilkin TJ. Developments in the prediction of type 1 diabetes mellitus, with special reference to insulin autoantibodies. Diabetes Metab Res Rev 2005; 21(5): 395-415.

http://dx.doi.org/10.1002/dmrr.554

[111] Wen L and Wong FS. How can the innate immune system influence autoimmunity in type 1 diabetes and other autoimmune disorders? Crit Rev Immunol 2005; 25(3): 22550

http://dx.doi.org/10.1615/CritRevlmmunol.v25.i3.40

[112] Bach JF. Infections and autoimmune diseases. J Autoimmun 2005; 25 Suppl: 74-80.

[113] Couper JJ. Environmental triggers of type 1 diabetes. J Paediatr Child Health 2001; 37(3): 218-20. http://dx.doi.org/10.1046/j.1440-1754.2001.00658.x

[114] Gale E. Viruses and type 1 diabetes: ignorance acquires a better vocabulary. Clin Exp Immunol 2012; 168(1): 1-4. http://dx.doi.org/10.1111/j.1365-2249.2011.04553.x

[115] Hintermann E and Christen U. Viral infection - a cure for type 1 diabetes? Curr Med Chem 2007; 14(19): 2048-52. http://dx.doi.org/10.2174/092986707781368397 
[116] von Herrath MG, Holz A, Homann D, Oldstone MB. Role of viruses in type I diabetes. Semin Immunol 1998; 10(1): 87100.

http://dx.doi.org/10.1006/smim.1997.0108

[117] Hannonen R, Komulainen J, Riikonen R, Ahonen T, Eklund $\mathrm{K}$, et al. Academic skills in children with early-onset type 1 diabetes: the effects of diabetes-related risk factors. Dev Med Child Neurol 2012; 54(5): 457-63. http://dx.doi.org/10.1111/j.1469-8749.2012.04248.x

[118] Pawłowicz M, Birkholz D, Niedźwiecki M, Balcerska A. Difficulties or mistakes in diagnosing type 1 diabetes in children?--demographic factors influencing delayed diagnosis. Pediatr Diabetes 2009; 10(8): 542-9. http://dx.doi.org/10.1111/j.1399-5448.2009.00516.x

[119] Nishio J, Gaglia JL, Turvey SE, Campbell C, Benoist C, et al. Islet recovery and reversal of murine type 1 diabetes in the absence of any infused spleen cell contribution. Science 2006; 311(5768): 1775-8. http://dx.doi.org/10.1126/science.1124004

[120] Stanger BZ, Tanaka AJ, Melton DA. Organ size is limited by the number of embryonic progenitor cells in the pancreas but not the liver. Nature 2007; 445(7130): 886-91. http://dx.doi.org/10.1038/nature05537
[121] Haller MJ, Atkinson MA, Schatz DA. Efforts to prevent and halt autoimmune beta cell destruction. Endocrinol Metab Clin North Am 2010; 39(3): 527-39. http://dx.doi.org/10.1016/j.ecl.2010.05.006

[122] Silverstein J, Klingensmith G, Copeland K, Plotnick L, Kaufman F, et al. Care of Children and Adolescents with Type 1 Diabetes: A Statement of the American Diabetes Association. Diabetes Care 2005; 28: 186-212. http://dx.doi.org/10.2337/diacare.28.1.186

[123] Gepts W, De Mey J. Islet cell survival determined by morphology. An immunocytochemical study of the islets of Langerhans in juvenile diabetes mellintus. Diabetes 1978; 27(S1): 251-61.

[124] Cooke D and Plotnick L. Type 1 diabetes mellitus in pediatrics. Pediatr Rev 2008; 29 (11): 374-84. http://dx.doi.org/10.1542/pir.29-11-374

[125] Amrani A, Verdaguer J, Thiessen S, Bou S, Santamaria P IL-1alpha, IL-1beta, and IFN-gamma mark beta cells for Fasdependent destruction by diabetogenic CD4(+) T lymphocytes. J Clin Invest 2000; 105(4): 459-68.

[126] Shalitin S and Philip M. The role of new technologies in treating children and adolescents with type 1 diabetes mellitus. Pediatric Diabetes 2007; 8(S6): 72-9. http://dx.doi.org/10.1111/j.1399-5448.2007.00279.x

Received on 02-03-2014

DOI: http://dx.doi.org/10.6000/1927-3037.2014.03.01.5

(C) 2014 Steve Yap; Licensee Lifescience Global.

This is an open access article licensed under the terms of the Creative Commons Attribution Non-Commercial License (http://creativecommons.org/licenses/by-nc/3.0/) which permits unrestricted, non-commercial use, distribution and reproduction in any medium, provided the work is properly cited. 